\title{
Veracity or Falsehood in the presidential elections of Peru and extreme parties.
}

\author{
Israel Mallma ${ }^{1}$, , Lita Salazar ${ }^{2} \unrhd$ \\ ${ }^{1}$ Doctor in Mining Safety and Control, Master's in mining management, Faculty of Mining Engineering, Graduate School \\ of the National University of the Center of Peru; israel_minner@hotmail.com \\ ${ }^{2}$ Doctor in Educational Sciences, Master's in educational management, Faculty of Education, graduate school of the \\ National University of the Center of Peru; litapierina@ hotmail.com
}

\begin{abstract}
Background and objectives: In the current context, the 2021 presidential elections in Peru distance from the social objective, not being objectively represented, that is why we analyze their validity, we determine the distances between the parties if they are extreme, the correspondences with the departments and their prospects, in the surveys we propose which departments influence the results.

Methods: We use a mixed methodology, qualitative analysis, it will be multidimensional with the support of statistical methods and programs such as R Studio, worddj, Gephi, and Iramuteq. The quantitative analysis will be through factor analysis, correspondence and discriminant analysis to the data of the election

Results and conclusions: The textual analysis mentions that there are dimensions such as the social issue, the results of the surveys and democracy that are far apart, regarding the electoral issue. This inculcates to work both on the part of the organisms that carry out these processes, as well as the initiative of the candidates, and the media. Regarding the quantitative analysis, it is detailed that the representative parties must be greater than 4.0 million voters, to make representative parties at the national level. The classification regarding the percentage of votes is given in three groups, highlighting the independence of the Peru Libre political party in these. In the correspondence analysis we can detail that both Fuerza Popular and Peru Libre are extremist parties. The vast majority of Peruvian citizens have an ideological tendency, intermediate between both parties. The prospective projections with a cross section give a victory to the Peru Libre party. In the discriminant analysis, the sample for the surveys focuses on 7 departments that does not include the Peruvian capital.
\end{abstract}

Keywords: Presidential elections, political parties, survey, democracy, supervisory bodies, Peruvian citizenship. 


\section{Introduction}

With $100 \%$ of the votes processed, Castillo (18.92\%) and Fujimori (13.4\%) finished in first and second place in a first round marked by the agitated political and social context in the country. Although it is true according to Corona et al. (2013, p. 23) the existence of the Principle of free, authentic and periodic elections in every democratic country.

But there is still a lot of misinformation, regarding this process in which the candidates who participate, regardless of the approach to the social issue of each of the political parties, there is a diversity of political parties that do not cover a minimum of normalized acceptance, a lot of responsibility in The JNE, who must watch over electoral processes and guaranteeing the citizen's will, and this is achieved with valid and prospective tools according to the current social context, these deplorable processes lead us down extremist paths, with which normally no Peruvian feels identified. This due to the question of what can be won an election with 2.7 million people, all these unusual contractual contradictions will be explained, lines below. Surveys that, in their absence, do not reflect the results obtained in the last elections, also have an approach in their interpretation, of which is the correct thing and not to fall into falsehoods in the sample of said surveys, for this we use the data resulting from the last elections. It is also highlighted which is the link with respect to the democracy of each one of the parties.

The political parties together account for around 7 percent of the citizen support and 15 percent of the benches at the parliamentary level. It is the biggest electoral failure of a group of organizations that until recently represented the vast majority of electoral supporters ... consequently, more and more politics appeared, before the eyes of the majority, as a space of inefficiency and lies (Tuesta, 1996 , pp. 67-69).

We consider that a profound renewal of the ruling class is necessary as an anti-corruption policy, for which it is necessary to modify an electoral system that protects immobility and political corruption in its many facets

... to end one of the causes of a good part of the evils of Italian politics: the proportional electoral system, which led the parties to obscure post-electoral compromises that distort the popular will (Beltrán De Felipe, 1993, p. 584).

On the subject of citizen participation we can detail that despite the mandatory nature of voting in 2016, according to the ONPE, only $83.46 \%$ of Peruvians vote and in 2021 only $70 \%$ of citizen participation according to the results at $100 \%$, where the candidates for the second round have 1.9 and 2.7 million votes from 25.3 million eligible voters. This leads to an analysis of representativeness in the presidential elections.

In the social aspect, it can be observed that within the election system, real and technical proposals are not proposed, the proposals are theoretical that are very far from the social perspective, issues such as poverty, education, diversity and foreign immigration and the behavior or response of the candidates to it.

The political parties must support democracy, the power of the entire Peruvian citizenry, but that this must demand the presence of candidates aligned with the anti-corruption framework and 
who support fundamental rights. In this part, a dimensional analysis of the electoral system with respect to rights and democracy is necessary. For this reason, in its development of the present, the forces existing between them are detailed.

And the results of the surveys, these analyzes, although they are results of samples and not of the universe, they must be kept out of a media spectacle and must be supported by an objective analysis within the current framework.

Kuschick Ramos (2013, p. 71), it can be affirmed that the opinion polls of 2012 were incorporated into the media as part of the media spectacle, with limitations in the calculation of the sample and the modalities of selection of the interviewees, which made possible errors in the application of the surveys.

\section{Materials and methods}

We use a Mixed methodology, in the qualitative analysis we will use discourse analysis and lexicometry with a multidimensional analysis, and in the quantitative analysis, we use factor analysis, hierarchical classification, correspondence and discriminant analysis, all of which will help us to achieve a contextual interpretation of the presidential and congressional elections held in 2021,

The data of 35 articles were analyzed with the R Studio software, worddj, Iramuteq and Nvivo and they detail the dimensions of the field to be studied, the qualitative data will have a statistical analysis and probabilistic carried out in Spss 25.

The data of the congressional elections were analyzed and updated on April 27, 2021 (minutes counted: $99.888 \%$ ) In the case of the analysis of the presidential data, it is April 30, 2021 where the (recorded minutes: $99.952 \%$ ).

\section{Textual analysis}

In summary, we could say the existence of three groups to analyze, the electoral system, rights and democracy, the latter includes the analysis of corruption, the environmental issue, among others, as can be seen in Figure 3 (A). In the textual analysis it can be observed that the electoral system is far from the polls, the social issue, and its requirements according to the current situation and democracy.

For the lexicological analysis we start with the correlation of the logarithm of word occurrence (x-axis) with the logarithm of frequency of use, which shows us a trend analysis in the figure, complying with the law of the so-called Zipf's law as detailed in the following expression:

$$
\text { Zipf's law expresses the following: } P_{n} \sim \frac{1}{n^{a}}
$$

Where:

Pn: represents the frequency of a word in the nth position (the words are ordered from highest to lowest frequency) 


\section{a: about 1}

This explains that the second element of a series will repeat approximately $1 / 2$ the frequency of the first.

Figure 1 Linear representation of the frequency of words in which the theory expressed by Zipf is fulfilled.

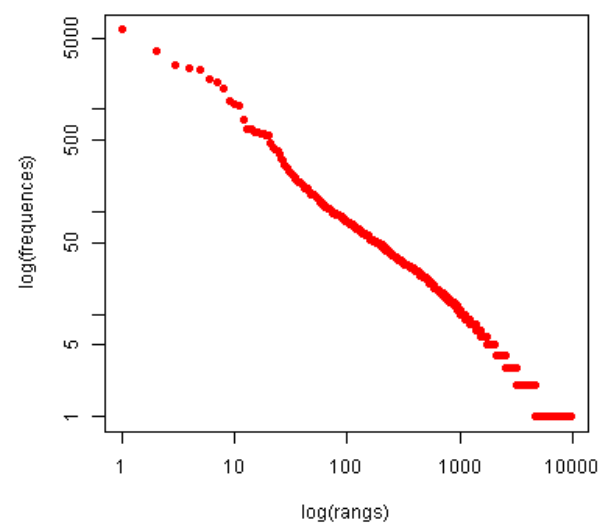

Below we can see the spatial representation, where it is not stated that the electoral system is far from the polls, the social issue, and its requirements according to the current situation and democracy.

Democracy is not being linked within the parties registered in the elections, and its candidates are even worse aligned with it, in figure $2(A)$ and (B) you can also see this grouping in which you can see what exists a rapprochement between the electoral system and the parties, but which is far removed, from the social issue of democracy, and from the polls that do not reflect the current situation, but which do have a powerful influence on the electoral system such as It is mentioned by various investigations.

Figure 2 (A) Multidimensional classification of the textual analysis and (B) Representation of the dendrogram for the analysis of distances in the dimensions.

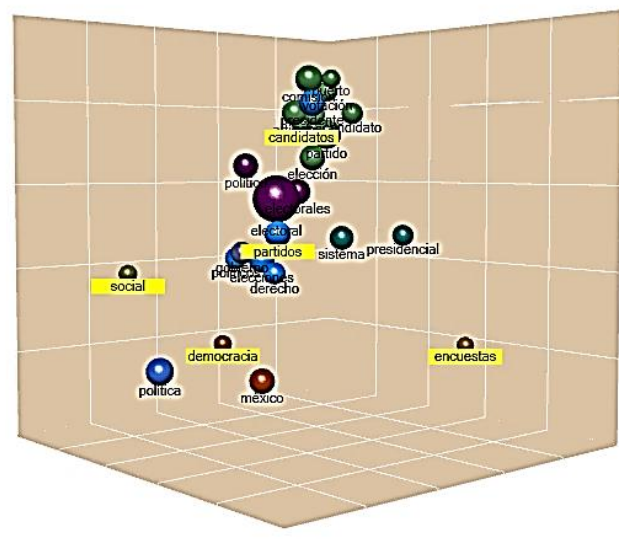

(A)

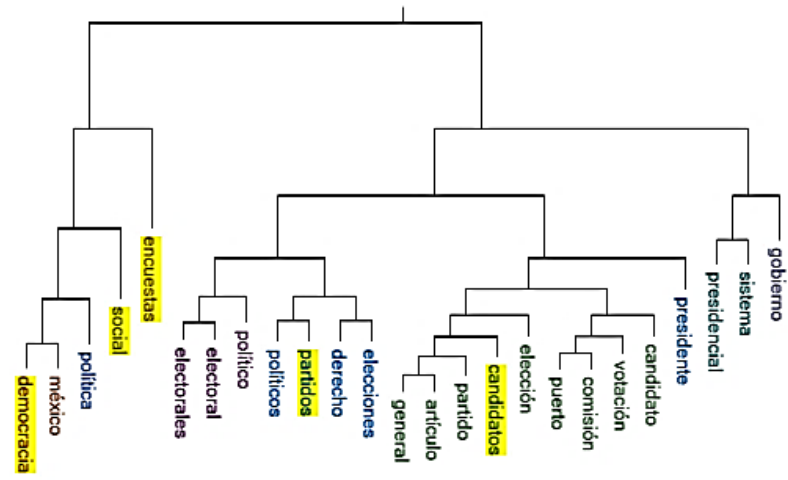

(B)

We also observe that the literature can be grouped into two main factors of 52.6 and 47 percent respectively, and it again mentions that the electoral system is far from the social responsibility of the issue of corruption, the environmental issue and the democracy, and social ethics is far 
removed in the electoral system from what the organizations of the countries propose, for this reason it is mentioned that it is necessary that the candidates have a link of integration with the aspects mentioned above.

The President of the Republic, although he does not have a mandate to govern and administer, is an authentic vector of social integration, to which the different social, cultural, economic and political forces are directed directly (Bragança \& Barroso, 1988, p. 308 )

The issue of Rights is also detached and segmented from the electoral issue, this last part that is inserted within the constitutions of the countries serves as a link from the social issue to the electoral one, so that a distance from this leads to the context as the that occurs in the current presidential elections of 2021.

It is important that the electoral system take on these two great dimensions that support democracy and the society that is the origin of any other system.

Regarding the surveys, we can detail that there is no relationship, regarding the vote of Peruvian citizens, ideology and cultural diversity, make it more diverse in their choice, there are parameters for their determination, but that they are aligned to Certain proposals from some parties will result in what happened in the last elections. For this reason, it is necessary in principle to analyze the correspondences and discriminate based on influential departments, a theoretical but scientific way that, failing that, will speak of other results that are more adjusted to the current context.

The IPSOS and Datum polls coincide in placing the daughter of former President Alberto Fujimori in first place with $12.9 \%$ of the votes. Yohny Lescano with $12.8 \%$ and López Aliaga (12.4\%). (AS Peru, 2021, p. 1)

Regarding the electoral surveys, the existence of absolute errors and standard errors regarding the presidential elections are detailed, due to this it is important, their analysis and respective calculation. (La Peña Mena, 2016) We will

propose compelling alternatives for the development of an adequate electoral process in line with the social and partisan ideological development, and of adequate communication for the coming processes.

In the social aspect, it can be observed that within the election system, real and technical proposals are not proposed, they are theoretical proposals that are very far from the social perspective. Electoral processes should have a greater social focus, in this way, greater credibility and electoral participation by the citizen will be achieved. And not focused on the delivery of credentials to certain public figures.

Corona et al. (2013, p. 51), It is proposed to seek means in which the evaluation and qualification of electoral processes can be made more social in order to achieve greater credibility on the part of the citizen, both in the institutions and in the processes in Yes. 
González Portillo and Jaráiz Arroyo (2020, pp. 1-2), Social inclusion policies have been analyzed from very different perspectives, those who design them (politicians) and those who execute them (technicians), the distance between the theoretical perception (political) and pragmatic perception (technical), as well as the need for both to be shared in order to improve the effectiveness of social inclusion policies.

There are studies in which it mentions that the political commitment resulting from mobilizations socialhas a positive effect in the framework of politics. So it could not be said that every mobilization has a negative focus on the development of politics.

Díaz Jiménez and Muñiz (2017, p. 1), While the theories of media malaise argue that media messages and campaigns have a negative impact on the political involvement of citizens, mobilization theories argue that the effect of Such messages about political commitment are rather positive. In general, the results of the analysis give greater support to the theories of mobilization than to the theories of media malaise.

The social issue must also analyze cultural diversity, which is not interpreted in a nonscientific way, in which there is a certain distance from the path of transculturality. Most of the studies mention the positive effects of immigration, and highlight the lack of delimitation of countries. It is considered that the economic factor is the main cause of said segregationist ideologies of some candidates.

Wallace and Wu (2019, p. 1), A study of Immigration and the quality of life in the metropolitan areas of the USA, mentions that it has positive and solid effects in the four dimensions of quality of life, economic well-being, social welfare, healthy life and urban mobility.

In this regard, several presidential standard-bearers criticize that the Peruvian country welcomed Venezuelans and blame them for an alleged increase in crime, although the problem of insecurity is not new in Peru, such as:

"Peruvians are fed up with the aggression of foreigners that they are carrying out hit men, assassinations or minor robberies ", affirms the ultra-conservative candidate Rafael López Aliaga.

"To deport and expel any foreigner who is in Peru in an irregular or illegal manner" the applicant Daniel Salaverry.

"Trucks of foreigners enter the Tumbes border (from Ecuador). "Where is the State to defend the Peruvian?", Says the popular former soccer player, the centerright candidate George Forsyth (Diario Gestión, 2021, pp. 1-2)

Figure 3 (A) Cartesian representation of the factors of the textual analysis ( B) Representation of the analysis of similarities with the Iramuteq software. 


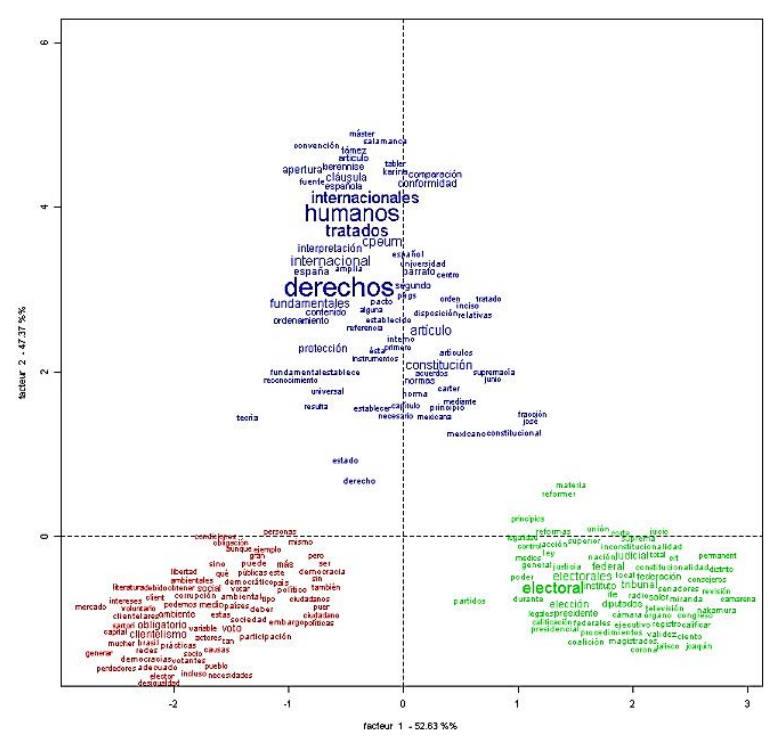

(A)

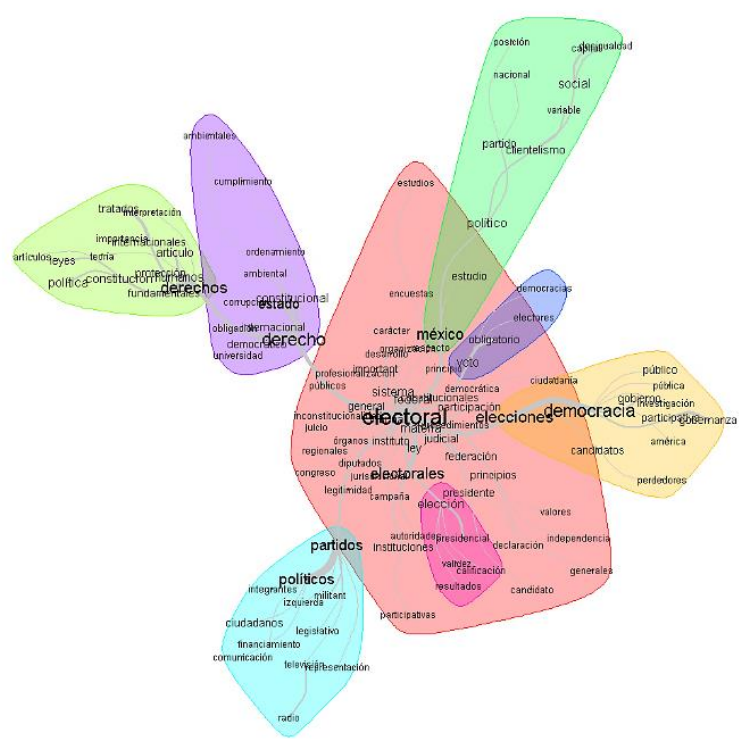

(B)

The similarity graph also details and emphasizes that the electoral system must link the political parties that support democracy and rights, regardless of who is in charge of assuming the presidency or any public office.

It should be noted that democracy is being affected by corruption, therefore the conduct of the candidates must be distanced from any form of dishonesty or crime committed by a person or organization that has been entrusted with a position of authority, and that seeks an illicit gain or abuse of power for personal gain. For this, the supervisory body imposes payments for infringement of said acts. As we can detail internationally.

Administrative fines are imposed for infractions to the provisions of this Act, to the aspiring candidates, independent candidates, elected officials and natural persons up to a maximum of one thousand dollars for the first infraction and up to a maximum of two thousand five hundred dollars for subsequent infractions by part of political parties. Campaign committees, or other legal entities and citizen groups certified by the Commission up to a maximum of ten thousand dollars for the first offense; and up to a maximum of twenty-five thousand dollars for subsequent infractions. (Rico et al., 2021, p. 47)

In the course of this decade, that political parties, and their representatives when they are elected by a nation, there is a tendency well marked for the benefit of their relatives and their supporters, many of them linked to corruption issues, although it is true that politics is understood as an economic benefit for certain groups. At present this conception has changed but even so it is observed that political parties continue to propose as candidates their families and businessmen who do not have an adequate record.

No person shall be recruited as a regular, transitory, irregular, contractor or outstanding employee when he or she has family ties with any proprietary member, 
ex officio, official or division chief of the Commission up to the second degree of consanguinity and up to the third degree of affinity. (Rico et al., 2021, p. 35)

In this last decade, they have proposed to eliminate certain privileges for the rulers, and this process of social construction is still being carried out. Certain privileges which are compared to the existing monarchies still still in some countries. They allow democracy to not develop adequately for the benefit of the common good.

Rico et al. (2021, p. 129) Members of the Legislature may only be separated from their positions, for (a) Having been convicted of a felony or a misdemeanor involving moral turpitude. (b) Engaging in immoral conduct. (c) Engaging in illegal acts that imply abandonment, inexcusable negligence or conduct harmful to the best public interests in the performance of their duties.

The data of the last presidential and congressional elections, we analyze it factorially, and the dimensions suggested in the analysis of the elections are detailed, then we will detail and analyze the percentages of the candidates, and we will propose their grouping, as well as their analysis of the results. that in its effect, leads to some fallacious situations, developed in said process.

\subsection{Validity of the elections}

With the results, we can detail that the number of people who participated in the electoral process is 17.6 million, out of 25.3 million voters, in summary we can detail that only $70 \%$ of the population participated in this process.

The candidates who passed to the second round have 2.7 and 2 million votes in their favor,

that is, with an average of 2.3 votes in a room of 25 people, the candidate is elected, these situations lead to not having an adequate analysis of the social context, and that the population does not agree with any representation of the candidates. Independent of any ideological or political tendency.

If we consider the total number of voters, which is 25.3 million, and we link them probabilistically within the normal curve, we will determine the minimum numbers by groups for the parties to meet the limit to be representative within an electoral process. Which gives us the following results:

Figure 4 Representation of the parties as a function of the number of voters within the normal curve.

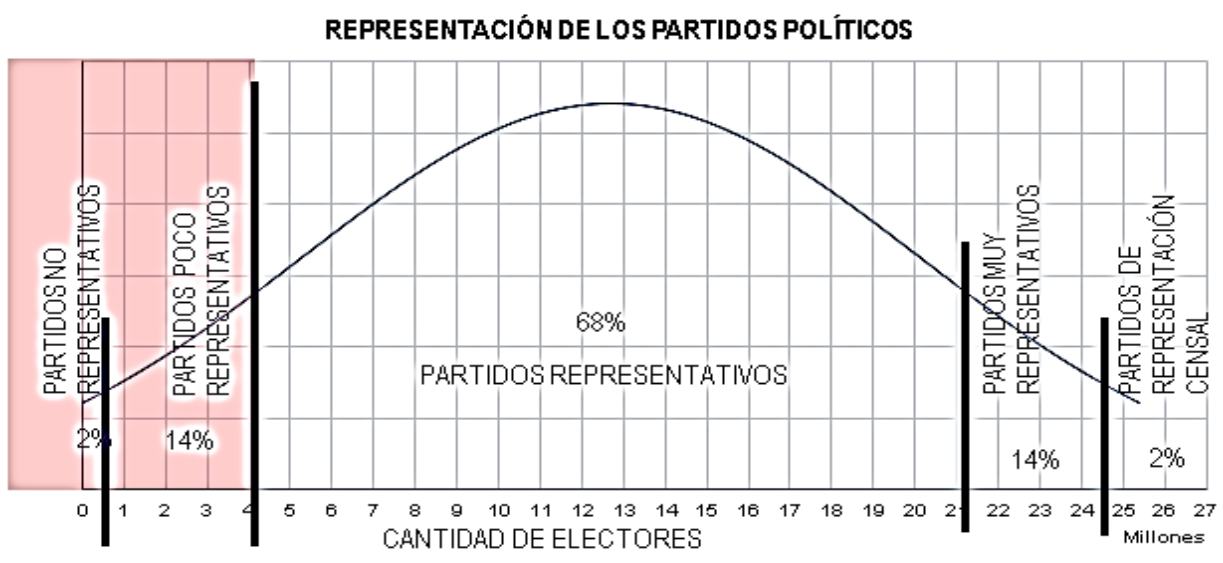


Figure 5 Valuation of political parties and calculations of the number of voters within the normal curve.

\begin{tabular}{|l|c|c|c|}
\hline \multicolumn{1}{|c|}{ SCORE } & PERCENTAGE & VOTER & CUMULATIVE VOTER \\
\hline Non-representative parties & $2.3 \%$ & 575301 & From 0-575301 \\
\hline Unrepresentative parties & $13.6 \%$ & $3,436,633$ & From 575,301 to 4,011,934 \\
\hline Representative parties & $68.3 \%$ & 17264086 & From 4 011 934 to 21 276 020 \\
\hline Very representative parties & $13.6 \%$ & 3436633 & $\begin{array}{c}\text { From 21 276 020 to } 24712 \\
653\end{array}$ \\
\hline Parties with census acceptance & $2.3 \%$ & 575301 & $\begin{array}{c}\text { From 24 712 653 to } 25287 \\
954\end{array}$ \\
\hline \multicolumn{2}{|c|}{ Total intervals } & 25287954 & \\
\hline
\end{tabular}

How we can observe only considering 25.29 million voters, the limit shows us that a minimum of 4.0 million voters is required for their representation within an electoral process. This suggests that the current candidates do not have representation within the probabilistic framework in which it takes place in the Peruvian elections.

The ONPE, whose function is to organize electoral processes, referendums and other types of popular consultation, developing the entire process that includes planning, organization and execution, and the JNE that of administering justice in electoral matters and that of supervising the legality of the exercise of suffrage and the conduct of electoral processes. Both bodies under which the entire electoral process falls. The existence of organizations that only come to give credentials to politicians, and not having current consultation parameters for the citizen context remains a question and without an answer.

"Despite the mandatory nature of voting in 2016, according to the ONPE, only $83.46 \%$ of Peruvians vote within a population of 23 million with the possibility of voting." (Núñez, 2020, p. 8)

Even worse when in these 2021 elections no one supports the legitimacy of the elections with 14.4 million valid votes and there are 1.1 million invalid votes and 2.1 million blank votes. The 3.3 million nulls and whites are more than either of the two presidential candidates. This will mark in history, the lags that the process is deplorable in all its dimensions.

\subsection{Analysis of the results}

\subsubsection{Classification of political parties}

From the results obtained by percentage of each party, the results of the dendrogram mention that the first group $(16,20,2,3,18,8,1,7)$ is included of 8 political parties that they include the percentage of voters who voted null and void, the second group to be analyzed is made up of 11 political parties $(6,12,15,4,5,17,19,10,14,9,11)$ that have a percentage vote similar probabilistic. It should be noted that the Fuerza Popular political party is within group 1. 
The Peru Libre political party (13) includes an independent group by the percentage of voters but that does not cover the minimum amount to belong to parties that are representatively in the Peruvian society.

Figure 6 Classifying dendrogram of the groups of political parties

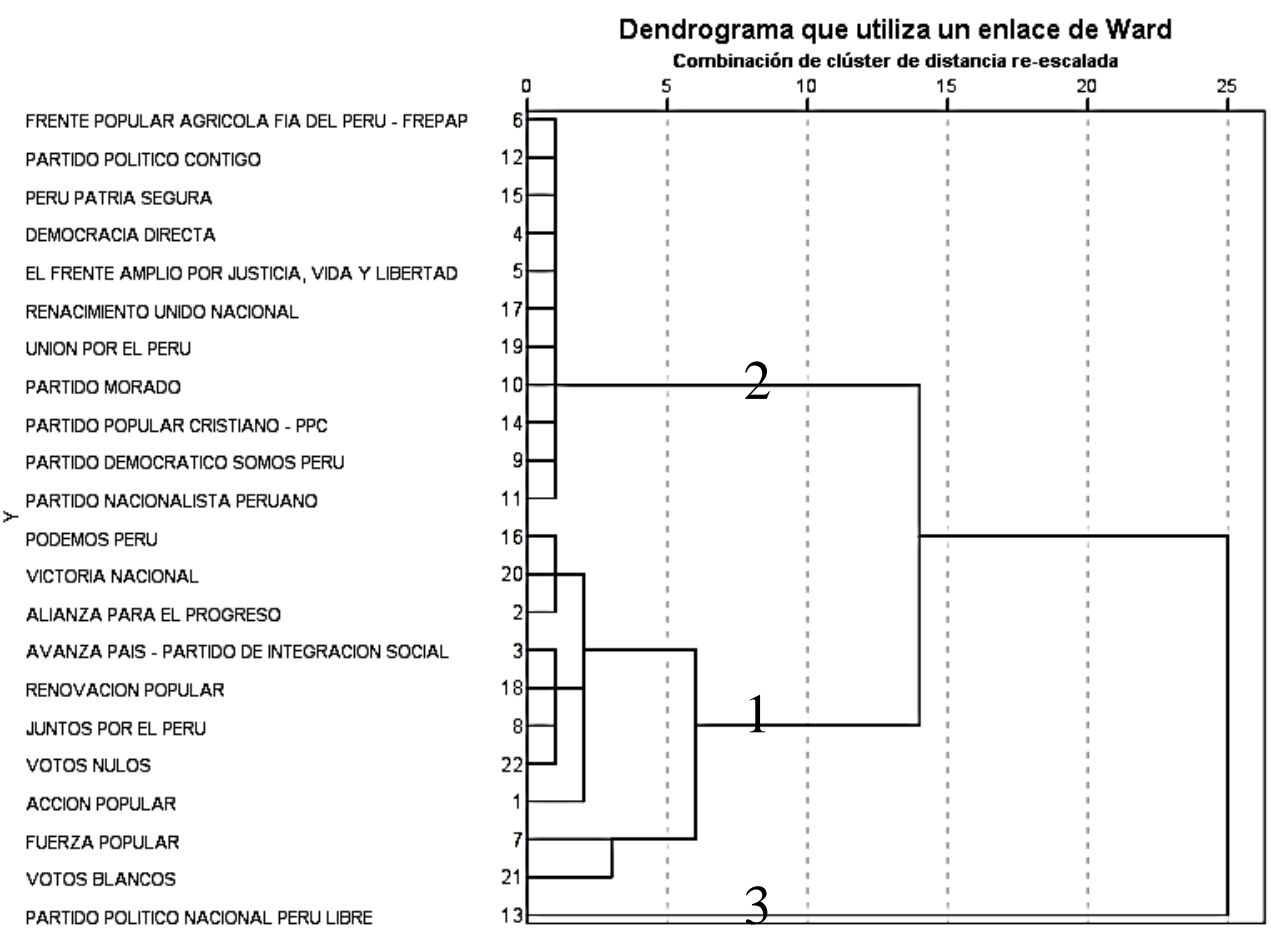

The analysis of the dendrogram allows us to determine the number of groups, they will be analyzed factorially with their representation for later interpretation.

\subsubsection{Factor analysis}

For its representation and classification, a factor analysis was carried out regarding the percentage obtained by each political party, we classified it into three representative groups in which the Peru Libre party belongs to an independent group (3), and the Fuerza Popular party is grouped within the group (1)

This representation, according to the analysis carried out in three factors, shows us the graph in which it is detailed, the percentage closeness of votes and of both political parties with respect to the other parties. In figure 7 (B) we can detail its visual grouping for its respective analysis regarding the number of percentage votes given by the population to political parties.

Figure 7 (A) Dispersion graph of the political parties considering 3 factors, (B) Dispersion graph of the groups according to the Ward method in the election of the president. 


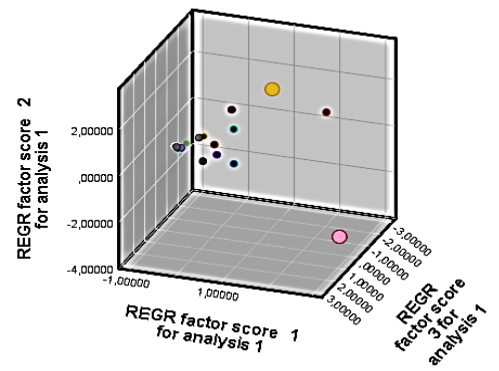

(A)

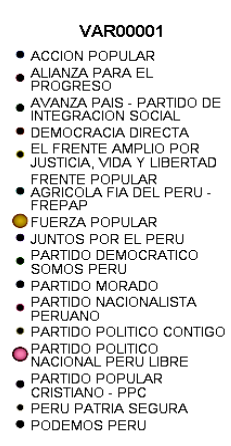

(B)

Note. Scatter diagram for the election of the president.

The analysis regarding the percentage obtained by the political parties for the election of the congressmen, we detail that it has almost the same scheme, as that of the presidential elections. As shown below.

What we can detail in the analysis of the congressional election, that the percentage of null and white votes forms an independent group as shown in figure 8 (B).

This explains the existence of elected congressmen, with minimal amounts of votes in their election.

Figure $8(A)$ Dispersion graph of political parties considering 3 factors, (B) Dispersion graph of groups according to the Ward method in the election of congressmen

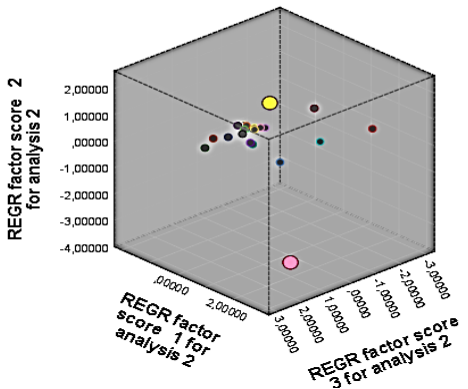

(A)

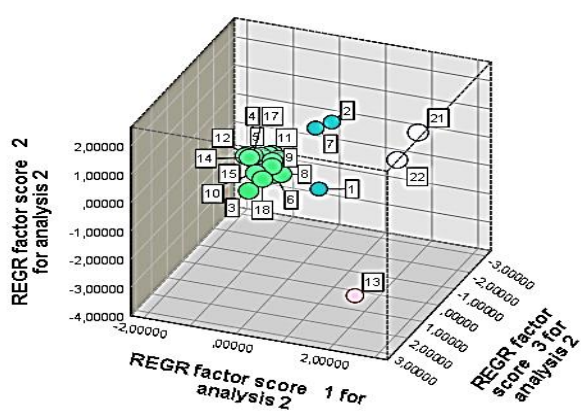

(B)

Note. Scatter diagram for the election of congressmen

If we take it to an analysis Regarding the centroids in departments and political parties we can detail the existence of very distant parties, regarding the percentage votes by departments we will only mention the party of Peru Patria Segura that is seen How far, the electoral context by departments of Peru,

apartThese figures are distanced, even more when we analyze the candidates for congress by party, according to the results of the ONPE updated to 05/07/2021, the candidates for congress: only obtained 52 votes in Junín (Renaissance joined Candidate No. 6), in Ancash with 7 votes (Renaissance joined candidate No. 6), and Patria Segura with 9 votes (candidate No. 6), in Ayacucho the PPC candidate No. 4 with 17 votes, and direct democracy candidate No. 4 with 16 votes. In Cuzco with 26 votes, candidate No. 6 from Patria Segura. In Tacna Candidate No. 4 with 10 votes for a safe homeland and thus we can cite in various departments. 
In the parliament in general there are candidates with minority votes with 37 (candidate 16) and 81 (candidate 14) from the direct democracy and broad front parties respectively.

Figure 9 Dispersion and correspondence graph of departments and political parties, and their respective centroids.

\section{Results and discussions}

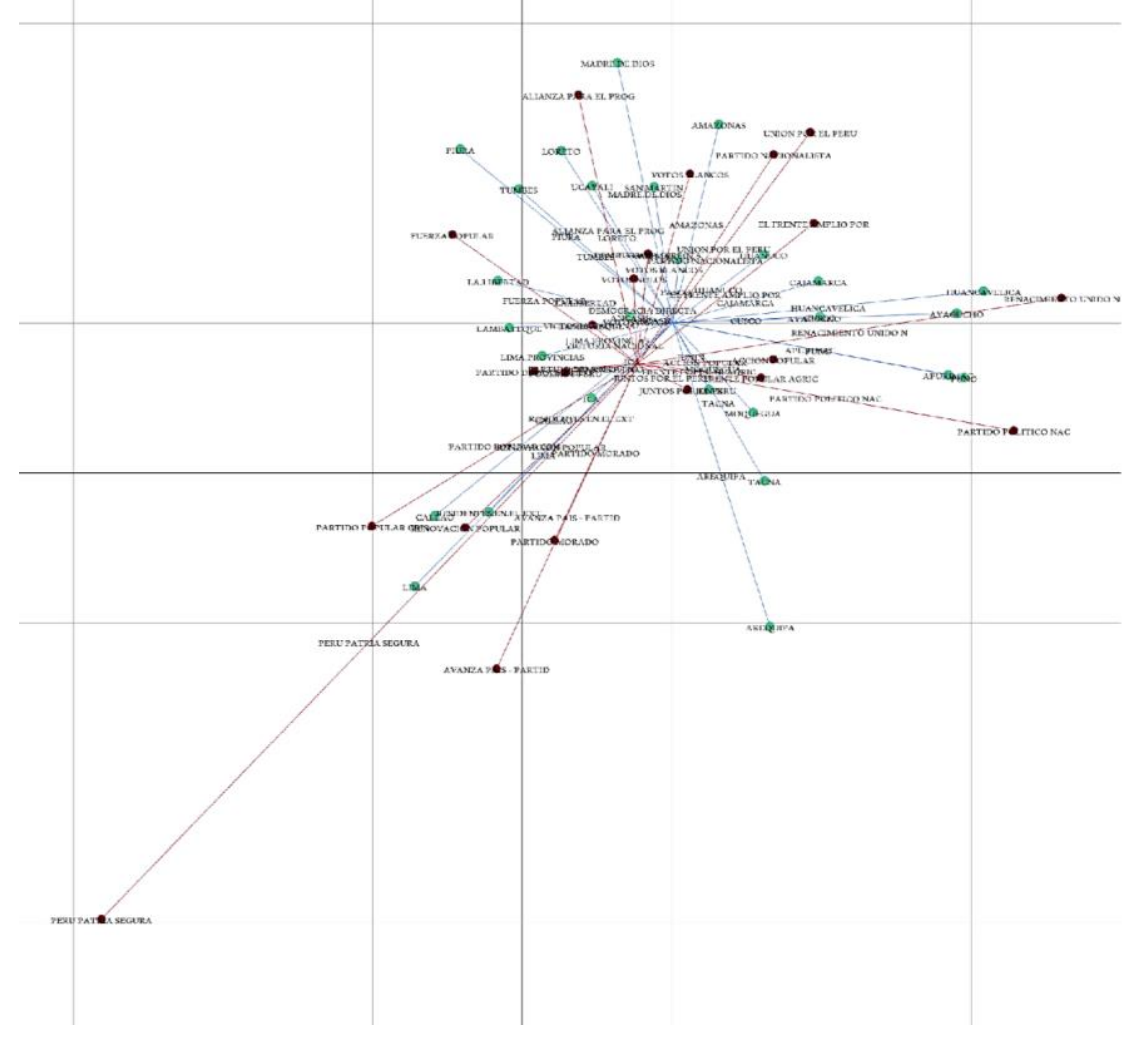

If we do a correspondence analysis by department regarding the parties that participated in the elections, we can detail that: The Fuerza Popular party and the Peru Libre party are both extremes, which means a difference with respect to the social perception in which we are For Peruvian citizens, the correspondence of the departments for the Peru Libre party includes 9 departments, as can be seen in the circular frame.

The number of departments that are closer to the Popular Force party are 8 departments.

As can be seen, there are 8 departments, which are very far from these political parties. Interview, this entails a partial segregation of the Peruvian ideology with respect to the extreme parties, which did not cover the average representation in the current social context. Both extreme parties do not represent the social ideal, nor the representative majority of Peruvians, regardless of the philosophical and social ideal that each party proposes.

In Peru, the ideology within the political parties of the right and left have a very marked alternation in their representativeness, it should be noted that all of them with the economic guidelines of the neoliberal model

The conservative position as Ortiz and Muñoz call it (2021, p. 1 ) has occurred in Peru in the alternation of political parties in the presidency although all aligned, even Ollanta Humala, who had a progressive ideology, reached the economic guidelines 
of the neoliberal model. Ollanta Humala represented hope and change for the populations less well represented by the traditional parties, whether they live in the Sierra or in some disadvantaged neighborhoods of large cities and who engage in activities considered illegal (businesses and services called informal who do not pay taxes) (Durand \& Godard, 2007, p. 168)

On the one hand, he proposes the candidate of Fuerza Popular, where his success lies in the popular sectors, who attribute to his father the end of terrorism and economic crisis that the country went through in the 1980s.

Its success without discussing here the methods or the final results was based on alleviating the two terrible problems of Peruvian society: economic crisis with hyper inflation and terrorism (BBC, 2016, p. 2 )

On the other hand, the Peru Libre candidate owes the success to the fact that the left proposes that to defeat the neoliberal hegemony, another alternative must be proposed.

Neoliberal hegemony is fought by proposing an alternative hegemony, that is why the need for a new constitution that expresses it (Nicolás Lynch, 2021, p. 3)

The ideology of each political party must allow to give identity to the organization and be the engine of balance against social objectives, regardless of the satisfaction of merely individual interests.

Corona et al., The ideological factor in the parties has traits of influence on the behavior of its members, and although it is recognized that party members are not fully unified actors, they tend to converge in some substantive aspects of a programmatic and ideological, and not only in the goal of winning elections as is often assumed. (2013, p. 199)

Rottenbacher (2012, p. 4), recently, studies support that political conservatism is closely associated with a cognitive rigidity which is understood as a need for order, structure and closure, an intolerance to the ambiguity and a low tolerance for novelty and uncertainty. 
Figure 10 Correspondence graph of political parties and departments of Peru.

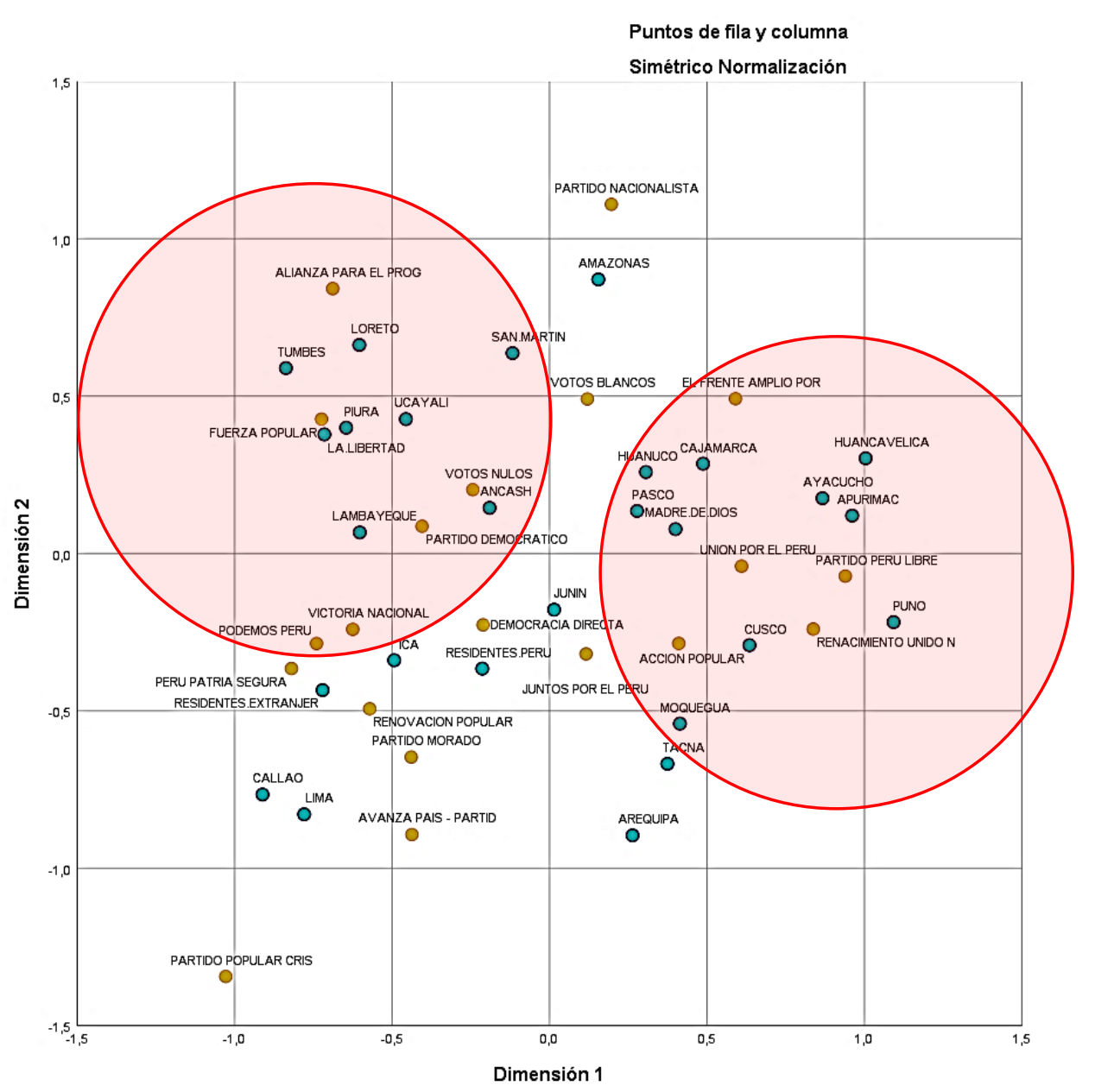

In the second electoral round, the electoral data allows us to mention that the Fuerza Popular party has 3 departments: Lima, $1 \%$ in favor of electoral difference (Peru Libre and Fuerza Popular), Loreto, $4 \%$, and Tumbes, with $3 \%$, that is, its difference is 1 to $3 \%$. It should be noted that residents abroad have a $4 \%$ difference in favor of Fuerza Popular.

Regarding the political party of Peru Libre, despite not meeting the requirement of national representation, it has a difference that ranges from 11 to $33 \%$ in the 21 remaining departments, only in the department of Ica in which it has a percentage in favor $3 \%$.

These differences in the percentage means obtained in the last electoral process, gives a prospect that said party would be the chosen one, many studies mention that the influence of the media determines the percentage variation with respect to the candidates, but that in crosssection From these analyzed results, the result is that the elected candidate will be that of the Peru Libre party. 
Table 1. Table of most influential means in the 24 departments in the grouped parties.

\begin{tabular}{|c|c|c|c|c|c|c|c|c|c|c|c|c|c|}
\hline \multicolumn{2}{|c|}{ Ward Method } & \multirow{2}{*}{ 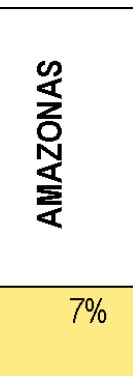 } & \multirow{2}{*}{ 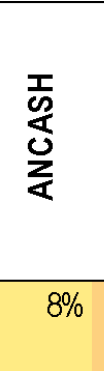 } & \multirow{2}{*}{ 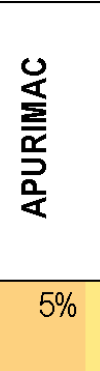 } & \multirow{2}{*}{ 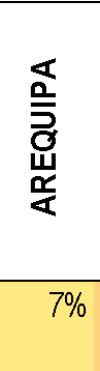 } & \multirow{2}{*}{ 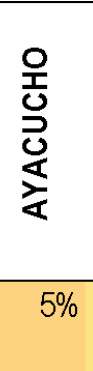 } & \multirow{2}{*}{ 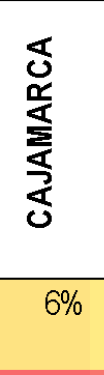 } & \multirow{2}{*}{$\begin{array}{l}\text { 옳 } \\
\text { 웡 }\end{array}$} & \multirow{2}{*}{$\begin{array}{l}\text { O } \\
\text { O } \\
0 \\
6 \%\end{array}$} & \multirow{2}{*}{ 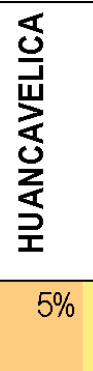 } & \multirow{2}{*}{ 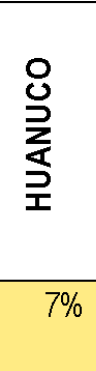 } & \multirow{2}{*}{$\begin{array}{l}\underset{\Xi}{\subseteq} \\
8 \%\end{array}$} & \multirow{2}{*}{$\begin{array}{r}\frac{2}{2} \\
7 \%\end{array}$} \\
\hline Clase 1 & $\begin{array}{l}\text { Media (Incluye Fuerza } \\
\text { Popular) }\end{array}$ & & & & & & & & & & & & \\
\hline Clase 2 & $\begin{array}{l}\text { Media (11 partidos } \\
\text { politicos) }\end{array}$ & $1 \%$ & $1 \%$ & $1 \%$ & $1 \%$ & $1 \%$ & $0 \%$ & $1 \%$ & $1 \%$ & $1 \%$ & $1 \%$ & $0 \%$ & $1 \%$ \\
\hline \multirow[t]{3}{*}{ Clase 3} & Media(Peru Libre) & $19 \%$ & $18 \%$ & $41 \%$ & $28 \%$ & $40 \%$ & $34 \%$ & $5 \%$ & $31 \%$ & $39 \%$ & $28 \%$ & $11 \%$ & $19 \%$ \\
\hline & Tota & $27 \%$ & $26 \%$ & $47 \%$ & $35 \%$ & $46 \%$ & $41 \%$ & $14 \%$ & $38 \%$ & $45 \%$ & $35 \%$ & $20 \%$ & $27 \%$ \\
\hline & Dif. \% (Clas.3 -Clas.1) & $12 \%$ & $\nabla 11 \%$ & $36 \%$ & $223 \%$ & $35 \%$ & $28 \%$ & $-4 \%$ & $25 \%$ & $34 \%$ & $21 \%$ & $3 \%$ & $\mathrm{D} 12 \%$ \\
\hline
\end{tabular}

\begin{tabular}{|c|c|c|c|c|c|c|c|c|c|c|c|c|c|c|c|}
\hline \multicolumn{2}{|c|}{ Ward Method } & \multirow{2}{*}{ 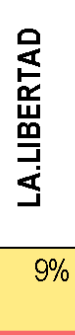 } & \multirow{2}{*}{ 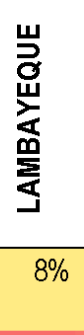 } & \multirow{2}{*}{$\begin{array}{l}\text { 舀 } \\
8 \%\end{array}$} & \multirow{2}{*}{$\begin{array}{r}\frac{\text { 음 }}{\text { 容 }} \\
8 \%\end{array}$} & \multirow{2}{*}{ 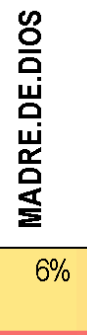 } & \multirow{2}{*}{ 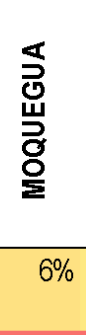 } & \multirow{2}{*}{ 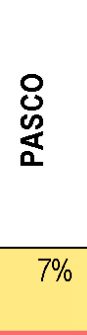 } & \multirow{2}{*}{$\begin{array}{l}\frac{\nwarrow}{\stackrel{\nwarrow}{口}} \\
\frac{\bar{D}}{\alpha} \\
8 \%\end{array}$} & \multirow{2}{*}{$\begin{array}{l}\sum_{2}^{\circ} \\
\text { 은 } \\
6 \%\end{array}$} & \multirow{2}{*}{ 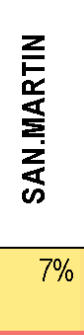 } & \multirow{2}{*}{$\begin{array}{l}\underset{\mathbf{S}}{\mathbb{E}} \\
6 \%\end{array}$} & \multirow{2}{*}{ 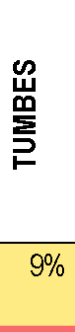 } & \multirow{2}{*}{ 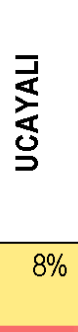 } & \multirow{2}{*}{ 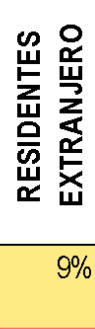 } \\
\hline Clase 1 & $\begin{array}{l}\text { Media (Incluye Fuerza } \\
\text { Popular) }\end{array}$ & & & & & & & & & & & & & & \\
\hline Clase 2 & $\begin{array}{l}\text { Media (11 partidos } \\
\text { politicos) }\end{array}$ & $0 \%$ & $0 \%$ & $1 \%$ & $1 \%$ & $1 \%$ & $1 \%$ & $1 \%$ & $1 \%$ & $0 \%$ & $1 \%$ & $1 \%$ & $0 \%$ & $0 \%$ & \\
\hline \multirow[t]{3}{*}{ Clase 3} & Media(Peru Libre) & $9 \%$ & $10 \%$ & $7 \%$ & $4 \%$ & $29 \%$ & $29 \%$ & $27 \%$ & $8 \%$ & $39 \%$ & $15 \%$ & $29 \%$ & $6 \%$ & $10 \%$ & $5^{\circ}$ \\
\hline & Total $(\%)$ & $18 \%$ & $19 \%$ & $16 \%$ & $13 \%$ & $36 \%$ & $36 \%$ & $34 \%$ & $17 \%$ & $45 \%$ & $23 \%$ & $36 \%$ & $15 \%$ & $19 \%$ & $14 \%$ \\
\hline & Dif. \% (Clas.3 -Clas.1) & $0 \%$ & $2 \%$ & $-1 \%$ & $-4 \%$ & $23 \%$ & $23 \%$ & $21 \%$ & $0 \%$ & $33 \%$ & $\triangle 8 \%$ & $23 \%$ & $-3 \%$ & $2 \%$ & $-4 \%$ \\
\hline
\end{tabular}

This also leads us to a discriminant analysis which will be limited and sectorized, the validity of the studies in the different departments and regarding electoral preference, this analysis is important to launch the validity of the surveys in the results. This is important, since currently there is a great diversity of information regarding the survey that results in invalid values regarding the political parties of the elections.

The analysis of means analyzed in percentage terms gave us an indication to determine which department could be evaluated to determine the proximity to the political parties, which went to the second round. But that a discriminant analysis would help us even more to determine which departments could be the respondents to have an overview of the real electoral context.

Performing an independent discriminant analysis, we detail that the department that reflects the most is the Fuerza Popular political party in the department of Ica. And the department that most reflects the Peru Libre party is Cajamarca, the department closest to the other political parties and to the null or flawed vote is the department of Junín. 
Table 2. Wilks Lambda table and its respective significance.

\begin{tabular}{lrrrr} 
Lambda de Witks & & & \\
\hline Prueba de funciones & $\begin{array}{c}\text { Lambda de } \\
\text { Wilks }\end{array}$ & Chi-cuadrado & gl & \multicolumn{1}{c}{ Sig. } \\
\hline 1 a 2 &, 000 & 122,034 & 32 &, 000 \\
2 &, 011 & 52,142 & 15 &, 000 \\
\hline
\end{tabular}

Table 3. Coefficients of the group classification functions (independent discrimination)

\begin{tabular}{|c|c|c|c|}
\hline & \multicolumn{3}{|c|}{ Ward Method } \\
\hline & 1 & 2 & 3 \\
\hline AMAZONAS & 2017,841 & 75,837 & 1427,598 \\
\hline ANCASH & 4290,893 & 109,711 & 11989,782 \\
\hline APURIMAC & $-2921,626$ & $-513,290$ & $-5339,418$ \\
\hline AREQUIPA & 140,979 & $-158,891$ & 8388,706 \\
\hline AYACUCHO & $-3029,659$ & $-219,780$ & $395 / 9, / 10$ \\
\hline CAJAMARCA & 1153,828 & $-497,404$ & 40860,062 \\
\hline CALLAO & $-1992,255$ & 32,280 & $-2177,099$ \\
\hline cusco & 1923,384 & 129,488 & $-9547,698$ \\
\hline HUANCAVELICA & $-2032,617$ & 391,066 & $-17614,570$ \\
\hline HUANUCO & 2057,730 & 401,072 & $-35735,013$ \\
\hline ICA & 4948,951 & 121,648 & 3076,814 \\
\hline JUNIN & 2366,116 & 466,561 & $-21130,518$ \\
\hline LA. LIBERTAD & 1437,334 & 259,053 & $-14370,066$ \\
\hline LAMBAYEQUE & $-2679,924$ & $-335,834$ & 19994,704 \\
\hline LORETO & $-899,821$ & $-102,849$ & $-2135,962$ \\
\hline PIURA & $-2836,737$ & $-58,292$ & $-9878,088$ \\
\hline (Constante) & $-180,827$ & $-2,828$ & $-4262,805$ \\
\hline
\end{tabular}

The discriminant analysis applying the method of inclusion by steps, for all groups 1-3 we can detail that the departments to be evaluated in a survey are the departments of Ancash, Ayacucho, Cusco, Huánuco, Junín, Loreto and Tacna respectively. In this way we will be able to give the appropriate information to the Peruvian citizens.

Table 4. Wilks' Lambda table and its respective significance.

\begin{tabular}{lrrrr} 
Lambda de Wilks & & & \\
\hline Prueba de funciones & $\begin{array}{c}\text { Lambda de } \\
\text { Wilks }\end{array}$ & Chi-cuadrado & gl & \multicolumn{1}{c}{ Sig. } \\
\hline 1 a 2 &, 001 & 117,744 & 14 &, 000 \\
2 &, 062 & 44,501 & 6 &, 000 \\
\hline
\end{tabular}

Table 5. Coefficients of the canonical discriminant function (inclusion discrimination by steps). 


\begin{tabular}{lcr}
\multicolumn{2}{c}{ Coeficientes de la función discriminante canónica } \\
\cline { 2 - 3 } & \multicolumn{2}{c}{ Función } \\
\hline ANCASH & $-195,338$ & \multicolumn{1}{c}{99,078} \\
AYACUCHO & $-230,131$ & $-96,589$ \\
CUSCO & 101,687 & 49,954 \\
HUANUCO & 185,792 & 1,911 \\
JUNIN & 78,118 & $-41,793$ \\
LORETO & 59,625 & 28,640 \\
TACNA & $-62,298$ & 46,771 \\
(Constante) & 2,968 & $-3,795$ \\
\hline Coeficientes no estandarizados
\end{tabular}

Below we show the territorial map that helps to study the relationships between the groups and the functions discriminant. Provides a graphical interpretation of the relationship between predictors and groups.

Figure 11 Territorial map-canonical discrimination.

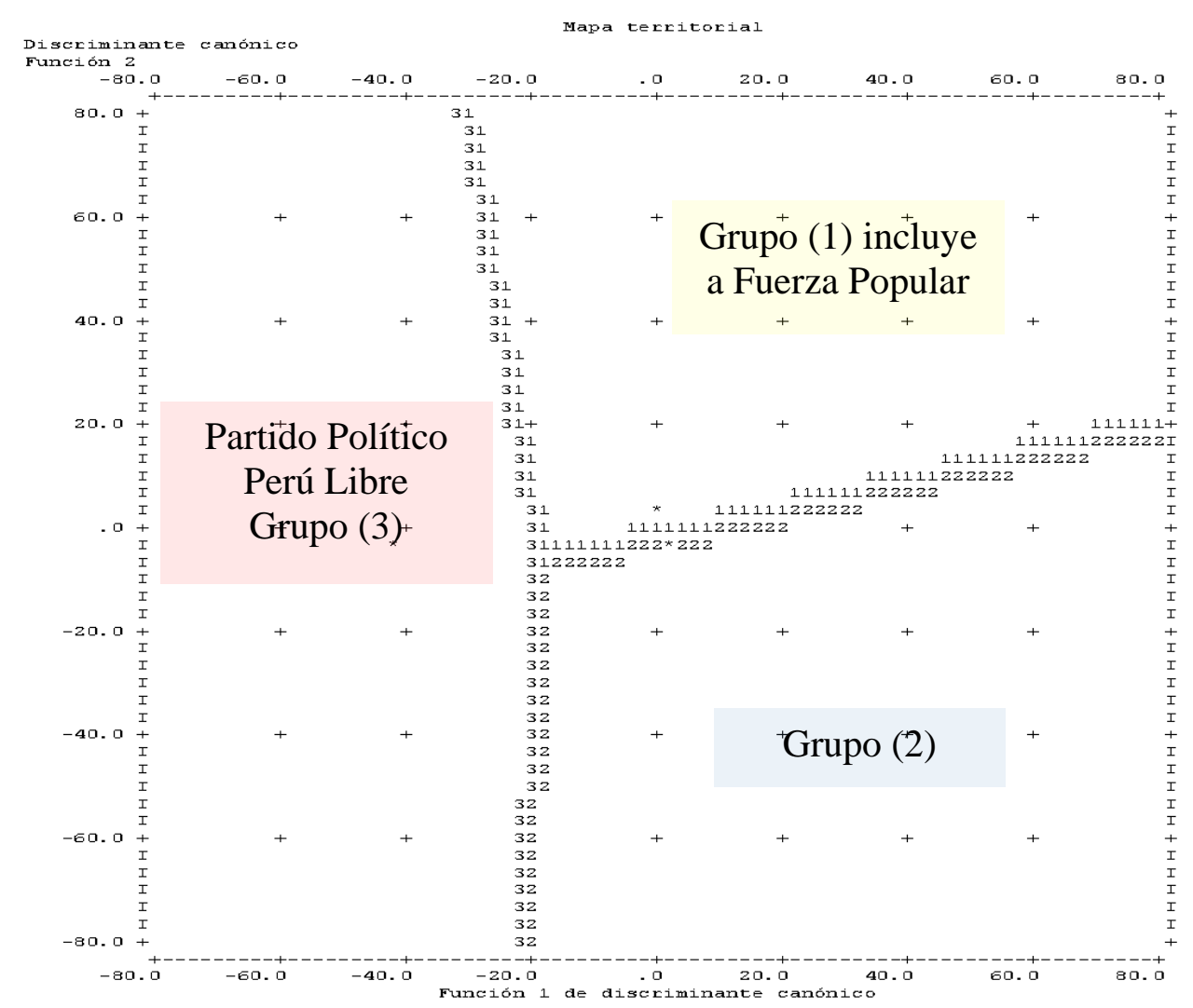

Communication has always been a means inclusive media in elections, so the survey results should be objective and have a treatment in its interpretation.

The media model that mostly dominated the scene and led to emotional citizen perceptions, with little public deliberation on the candidates' political proposals and competencies. The model of the use of social networks, its effects were relative to the conditioning of political actors and the media. The terrestrial model showed the permanence of voting conditioning mechanisms in some parts of the country, although its results were not very definitive (Meyer Rodríguez et al., 2013, p. 1). 
Fernández Poncela (2014, p. 131), in "the mother of the surveys on the war of the surveys 2012" mentions that it must be taken into account that the inferences of the survey are about the sample consulted and the population questioned, not about the universe and society as a whole.

For all these reasons, we consider that an analysis of the most representative departments, framed by the discriminant analysis, would be a modest option for treating the results of electoral surveys and avoiding errors.

\section{Conclusions.}

The textual analysis mentions that there are 3 dimensions such as the social issue, democracy and the electoral system, which must be linked and not independent, in addition to that, it mentions that the results of the polls and democracy are distanced, with respect to the electoral issue. . This inculcates to work both on the part of the organisms that carry out these processes, as well as the initiative of the candidates, and the media.

Regarding the quantitative analysis, it is detailed that the representative parties must be greater than 4.0 million voters, to make representative parties in the Peruvian citizenry.

In the percentage classification of the votes of the political parties, it occurs in three groups, highlighting the independence of the political party Peru Libre in a single group.

In the correspondence analysis we can detail that both Fuerza Popular and Peru Libre are extremist parties. The vast majority of Peruvian citizens have an ideological tendency, intermediate between both parties.

The prospective projections with a cross section at this time give a victory to Peru Libre.

In the discriminant analysis, for the survey sampling, the focus is on 7 departments that do not include the Peruvian capital, including Ancash, Ayacucho, Cusco, Huánuco, Junín, Loreto and Tacna.

\section{Author contributions}

In the present we will analyze the veracity or falsehood of the presidential elections of Peru 2021 and the extreme parties, with the use of qualitative and quantitative methodologies, and with the help of statistical processes and computer programs, an interpretation and a systemic contribution is given. of the investigation about the presidential electoral process of 2021 , in which it is determined that the representative parties in Peruvian citizenship must be greater than 3.65 million voters, in the correspondence analysis we can detail that both Fuerza Popular and Peru Libre are extremist parties, and the majority of Peruvian citizens have an ideological tendency, intermediate between both parties, it is recommended that the surveys should be focused on 7 departments that do not include the Peruvian capital.

\section{Conflict of interest}

The authors declare that this article was carried out in the absence of commercial or financial relationships that could be interpreted as a possible conflict of interest.

\section{Expressions of gratitude}

The authors wish to thank the reviewers for their valuable comments, aimed at improving the communication, effectiveness, and overall quality of this manuscript. 


\section{Bibliographic reference}

AS Peru (2021). Peru elections 2021 _ results of the latest polls, who is winning and the intention to vote candidates - AS Peru. AS Peru.

Astigueta, M. (2018). Political speech. Political Marketing Short Handbook, 100 Communication Tips for Candidates and Serving Officials, 3-4.

BBC (2016). Why does Fujimorism continue to be strong in some sectors of Peru? https://www.bbc.com/mundo/noticias/2016/04/160318_peru_elecciones_fujimorismo_ep

Beltrán De Felipe, M. (1993). The New Italian Local Electoral Law (Law of March 25, 1993 No. 81 of Election Directof Provincial Mayors and Presidents). Journal of Local and Autonomous Administration Studies, 59(1988). https://doi.org/10.24965/reala.vi259.8793

Bragança, J., \& Barroso, A. (1988). The President of the Republic: Function and powers. Journal of Political Studies(60), 307-332.

Corona, L., Miranda, A., La Tames, K. de, Gallardo, A., Veldez, S., \& Bonatti, G. (2013). Democracy and Elections. Ratio Legis Library Jurídica, 53(9), 1689-1699.

Management Newspaper (2021). Venezuelan migrants, subject of dispute in the electoral campaign in Peru_PERÚ _ GESTIÓN. Management - Policy.

Díaz Jiménez,OF, \& Muñiz, C. (2017). The Effects of Political Communication on the Political Engagement of Young People in the Mexican Presidential Election of 2012. Revista Mexicana De Ciencias Politicas Y Sociales, 62(229), 181-221. https://doi.org/10.1016/S0185-1918(17)30008-9

Durand, M., \& Godard, H. (2007). The presidential elections in Peru in 2006: an indicator of socio-spatial segregation and social protest. Bulletin De L'institut Français D'études Andines, 36(36 (1)), 165-170. https://doi.org/10.4000/bifea.4699

Fernández Poncela, A. M. (2014). The mother of polls on the poll war 2012. Revista Mexicana De Opinion Pública, 17, 110-133. https://doi.org/10.1016/s1870-7300(14)70902-0

González Portillo, A., \& Jaraíz Arroyo, G. (2020). Social inclusion policies in Andalusia from the discursive perspective and lexicometry. A comparative analysis of the technical-political discourse. Empiria. Journal of Social Sciences Methodology(45), 75.

https://doi.org/10.5944/empiria.45.2020.26305

Kuschick Ramos, M. (2013). The Polls and the 2012 Elections: Some Critical Reflections. Mexican Journal of Public Opinion, 14, 70-92. https://doi.org/10.1016/s1870-7300(13)723159

La Peña Mena, R. de (2016). The debate on electoral polls in Mexico in 2012. Revista Mexicana De Opinion Pública, 20, 53-81. https://doi.org/10.1016/j.rmop.2015.12.004

Meyer Rodríguez, J. A., Ríos Calleja,Cl, Sánchez Nuevo, L. A., \& Bañuelos Ramírez,RM (2013). Significance and effect of media communication in the 2012 presidential campaign. Revista Mexicana De Opinión Pública, 14, 30-47. https://doi.org/10.1016/s18707300(13)72313-5

Nicolás Lynch (2021). Why did Pedro Castillo win? By Nicolás Lynch. Nodal. 
Núñez, I. M. (2020). Presidential elections in El Salvador 2019: the defeat of the FMLN and a new government with Nayib Bukele. Latin American Yearbook - Political Sciences and International Relations, 9, 173. https://doi.org/10.17951/al.2020.9.173-193

Ortiz,RYO, \& Muñoz, M. E. P. (2021). The presidential elections in the USA 2012-2016. A comparative study from a state and individual perspective. North America, 16(1), 1-29. https://doi.org/10.22201/CISAN.24487228E.2021.1.449

Rico, P., Xxi, S., Compulsorias, P. P., Presidencial, V., Residents,CA, Los, DEM, Electoral, R., \& Art, E. (2021). 2020 Puerto Rico Electoral Code, 1-189. www.ogp.pr.gov

Rottenbacher, J. M. (2012). Validity of the left / right ideological continuum during the 2011 presidential elections in Lima - Peru. Journal of Psychology, 30(2), 281-315. https://doi.org/10.18800/psico.201202.003

Tuesta, F. (1996). The presidential elections in Peru. University of Salamanca.

Wallace, M., \& Wu, Q. (2019). Immigration and the quality of life in US metropolitan areas. Social Science Journal, 56(4), 443-457. https://doi.org/10.1016/j.soscij.2018.09.016 